\title{
The Clash of Gendered Referents in Mary Wollstonecraft's A Vindication of the Rights of Men
}

\author{
Gariti Mohamed \\ Department of English, Mouloud Mammeri University of Tizi-Ouzou, Algeria \\ Sabrina Zerar \\ Department of English, Mouloud Mammeri University of Tizi-Ouzou, Algeria
}

\begin{abstract}
Whenever critics talk about Mary Wollstonecraft's commitment to feminism, they very often turn to her $A$ vindication of the rights of woman for illustration. Her $A$ vindication of the rights of men is rarely referred to in this regard, though it constitutes the conceptual basis of her later reflection on gender power relationships. Taking its bearings from Mikhail Bakhtin's (1999) dialogic theory of discourse and the sociological theorization of space developed by Jurgen Habermas (2010) in his The structural transformation of the public Sphere, this paper argues that $A$ vindication of the rights of men, much more than its sequel $A$ vindication of the rights of woman is the one discursive space wherein Wollstonecraft clashes with the best male brains of her time (Burke, Rousseau, etc). The clashes concerned include, though not entirely confined to British constitutional history, the bourgeois family, aesthetics, and the impact of civilization on the shaping of the new society heralded by the French Revolution.
\end{abstract}

Index Terms-Wollstonecraft, Burke, dialogism, French Revolution, feminism, Rights of Men

\section{INTRODUCTION}

The French Revolution (1789-1799) and the debate it generated about the rights of man among liberal circles and radicals such as: Joseph Price, Joseph Johnson, Thomas Paine, and William Godwin prepared for the re-emergence of the feminist voice and presence in the public sphere at the turn of the eighteenth century. A century earlier, the Glorious Revolution had allowed for the development of similar feminist concerns in Britain. If two British women authors have to be chosen as representatives of the redeployment of emancipation discourse against the exclusion of females from the public sphere during these two critical periods, Mary Astell and her namesake Mary Wollstonecraft will certainly come to mind. Just as Astell had appropriated the prevalent libertarian discourse of the Glorious Revolution in defence of women's emancipation in works like Some reflections upon marriage, Wollstonecraft in A vindication of the rights of men borrowed similar conceptual bases from the rhetoric developed around the French Revolution to dislodge the separation of the private from the public sphere in the bourgeois patriarchal order. This parallel will not be continued here, for Wollstonecraft's work alone is sufficient for arguing the point that the circulation of emancipation discourse in revolutionary times is often appropriated by committed female authors for abrogating the empire of man over woman by widening male thinkers' claims for man's liberation to include that of woman. The widening of claims across gender lines often takes the shape of what Bakhtin calls a "clash over referents" such as gendered spaces, aesthetics, history, and the patriarchal family. To date, Wollstonecraft's feminist commitments have been discussed in relation to her $A$ vindication of the rights of woman, overlooking the crucial place that her $A$ vindications of the rights of men holds in her discussion of human rights across the gender lines. It is particularly in this work that on can see at work how the writer appropriates the prevalent, contemporary, male discourses about aesthetics, civilization, the family, and history in order to abrogate the major presumptions underlying the exclusion of women from the nascent political kingdom. Through both hidden and overt polemics, Wollstonecraft subverts the gendered discourse of her male contemporaries speaking in defense of gender-inclusive human rights and freedoms.

\section{DISCUSSION}

For a proper discussion of Wollstonecraft's feminist outlook, it would be more convenient to consider the principles or conceptual bases from which she tried to dismantle female sensibility as an ideology of femininity. This engagement is best revealed in A vindication of the rights of men, published in the form of serialized letters in Joseph Johnson's Analytical review in the last months of 1790 before being published anonymously in December of the same year. It was written in prompt response to Edmund Burke's Reflections on the revolution in France that appeared on 1 November 1790. Wollstonecraft's immediate rejoinder to Burke's essay was followed up by Paine's The rights of man (1791) and Godwin's Political justice (1793). The publication of these essays, sometimes in several reprints, and their wide 
circulation reveal the climate of heated debate triggered by the French Revolution among political circles with various political affiliations concerned with the nature and the directions that the revolution then going on across the Channel could take. Most of the debate turned around whether or not the French Revolution was similar to the Glorious Revolution. Some radical thinkers saw the former as a historical completion of the latter, whilst some liberals and conservatives denounced this as mere political confusion. The polemics that arose between Dr Price and Burke is representative of the debate about the French Revolution.

A dissenter, Dr. Price, under whose tutorship Wollstonecraft came to place herself, regarded the French Revolution as part and parcel of a providential history or plan for the completion of the thwarted human emancipation project set off by Glorious Revolution in 1689. In his various interventions in favour of the French Revolution, Price legitimized suppression of priesthood and hereditary political power, and the placement of the civil authority under the rule of reason. For him, that rule of reason on which the Glorious Revolution was originally founded was turned into mere custom and traditionalism in the hands of post-revolutionary political establishment in Britain. The French Revolution was nothing else than a rehabilitation of reason as a principle of government. Holding a strikingly different view about the history of these two revolutions, Burke dismissed in harsh terms Price for mixing genres, and the French revolutionaries for the abstract principles on which they had based their theory of revolution. The denunciation was carried out in the name of the British Constitution and prescriptive rights, both of them fashioned by a long historical development culminating in the moderate political settlement of the Glorious Revolution. For Burke, Price's providential history smacks of a leveling tendency that makes him kith and kin with both those French preaching aberrant "abstractions" about liberty, equality and freedom, and the ancestral Roundheads who had beheaded Charles I during the English Civil War in the 1640s. There was no comparison whatever to be made between the political and social situation in Britain and the one prevailing in France in the last decade of the eighteenth century, because the two countries were at significantly different stages of their historical development. The abuses of rank and status of the Old Regime the French were rebelling against had already been righted peacefully a century earlier in Britain through the imposition of a system of rights and duties. Through an astute "misreading" of British history, Burke elevates the English Monarchy and the Anglican Church, whose status quo Price wanted to undermine, into national symbols of Englishness. The belonging to the English nation, Burke suggests, is largely determined by the degree of reverence shown to these symbols, hence the implication that radicals like Price do not deserve to belong to that nation because of their affiliation with the French revolutionaries.

Given the prevalence of the separate spheres at the century's end in France and Britain, it is remarkable that Wollstonecraft dared at all to intervene publicly in the Price vs. Burke argument taking sides against the latter in defence of political rationalism and rational morality that Burke sought to undermine by his critique of the French Revolution. As can be expected, her strong commitment to these principles did not fail to relegate her to the margins of the nation. Homi K. Bhabha (1990) defines nationalism as "an idea whose cultural compulsion lies in the impossible unity of the nation" (p.1). He adds that the "location" of national culture is neither unified nor unitary in relation to itself, nor must it be seen simply as "other" in relation to what is outside or beyond it" (p.4). What Bhabha underlines is that "othering" happens simultaneously inside and outside the national boundaries with the imagining of the national community as a masculine character and the other inside and outside as feminine. Nationalism "engenders" more than it dislodges gender, and that largely explains that women were deeply divided as to the position they must observe towards the French Revolution. While some of them like Mary Wollstonecraft, Catherine Macaulay Graham, and H. M. Williams transgressed gender boundaries in voicing their own opinion in favour of human emancipation, others like Laeticia Matilda Hawkins sought to consolidate the political establishment. Hawkins's admonishment to Williams who wrote letters from France in defence of the Revolution are quite illustrative of the point we want to make:

But the points of 'A King or No King A Nobility or no Nobility?' [a title of one of her letters] are not those, my dear madam, which I mean to discuss with you. I would rather convince you that they are points neither you nor I can discuss with propriety or success; that there is but one side a female can take in politics, without injuring the feminine character. (Quoted in Jones, p.117)

Obviously, for Hawkins, politics is beyond women's ken, and it would be pretentious and injurious for her femininity to enter the public sphere of politics. Interwoven in this discourse is the traditional division between the good and the bad sort of femininity.

As already pointed out, Wollstonecraft did not only intrude into the public sphere of political activity but dared to argue with one of the most distinguishable British statesmen of the time. Her feminism is a militant feminism in the sense that she did not write for an academic audience as some feminists are prone to do, but for the public at large to fashion their opinion as to the importance of the rights of men that Burke tried to stifle in the name of the political establishment. So what are the major arguments that she leveled against the conservative Burke, and in what style she made them? In addressing her A vindication of the rights of men directly to Burke, Wollstonecraft disregarded one of the most important foundations of the ideology of femininity in the eighteenth century, which is modesty. Written in the epistolary mode, the book gives the impression that Wollstonecraft is a rebelling daughter who has decided to speak the truth to a conservative father of the nation who stands as an obstacle to the advance of the rights of men. Diane Long Hoeveler (1998) sees Wollstonecraft as the one woman essayist who, by her A vindication of the rights of woman (1792) laid down the aesthetic theory for the writing of women's gothic fiction such as the one produced by Anne Radcliff and 
the Brontès. Though one could agree with Hoeveler as to the influence that Wollstonecraft might have exerted on the writing of women's gothic fiction, the source of influence cannot be circumscribed solely to A vindication of the rights of woman as Hoeveler has done in her analysis. It includes $A$ vindication of the rights of men. Indeed, it is in this latter work that the principles of Gothic feminism were at first formulated to be later refined and revised in its sequel $A$ vindication of the rights of woman, all in accordance to the historical evolution of politics in France and England. If gothic feminism, as Hoeveler claims, is marked by a struggle between aggressive heroines and tyrannical fathers and decadent aristocratic and priestly figures, who are symbolically wounded and humanized before readmitted as friendly companions to women, it is in A vindication of the rights of man that such psychological dramatization has to be sought.

Wollstonecraft's personal drama played up against the background of the controversial debate over the French Revolution in $A$ vindication of the rights of men resembles in many respects the dramas developed in gothic fictions by Anne Radcliff's The mysteries of Udolpho and Charlotte Bronte's Jane Eyre. The verbal thrusts that Wollstonecraft directs at Burke the surrogate father in the domestic sphere (home and country) announces both the two gun shots that the gothic villain, Valencourt, receives in the Radcliff's fiction, and the blinding and amputation that Rochester underwent in Charlotte Brontë 's Jane Eyre. Moreover, just as in gothic fiction, the heroine-author Wollstonecraft while involved in a symbolic character assassination of the bad fatherly figure Burke, makes Richard Price appear as the wished-for feminized, civilized or tamed father that she herself had not had in her real life. Just as gothic heroines of Radcliff and the Brontè s, Wollstonecraft proceeds to the purging of the bourgeois ethos and morality of aristocratic vices. However, in Wollstonecraft's essay, the heroine-author does not behave as a victim, the other side that Hoeveler identifies as another characteristic of the gothic heroine. Of the latter, Hoeveler (1998)writes that "by presenting herself as an innocent and suffering victim, by masquerading as the beleaguered heroine, the gothic feminist actually positions herself for the assault, shielded, of course, from the charge or even the impression that she is the aggressor" (p.14). It is rather of the assault on Burke that we read in Wollstonecraft's A vindication of the rights of men. Her personal drama, in which indeed she appears as a victim, transpires only as an implicit background that the reader has to fetch from auto/biographical information outside her "gothic" essay. On the other hand, as already suggested above, one can see at work a wished-for construction of a bourgeois family type at whose head is the feminized, civilized Richard Price. Metaphorically, the latter has put an end to the gendered economic disfranchisement by leaving an intellectual legacy to his adopted daughter (Wollstonecraft), thus metaphorically erasing the primogeniture law and patrimonialism (inheritance through the male) and patrinearity (naming practices).If Burke is chastened, it is because his attack against Price in defence of a dying aristocratic system has turned into character assassination of a wished-for civilized bourgeois father and a reshaped bourgeois family shorn off the excesses of the aristocratic order.

The ideal of 'masculinity' or rather 'manliness' is blatantly assumed by Wollstonecraft in the plural form of the noun "men" in the title of her book. In her first argument, she tells this father of the nation (Burke) that "she has not learned to twist her periods" (Wollstonecraft, 1999, p.5), nor to indulge in innuendoes in expressing her argument, putting herself outside the boundaries of traditional womanhood for whom such outspokenness was synonymous with impudence. No sooner had she made this concession than Wollstonecraft launched her attacks on Burke by mustering such hurtful epithets as "vain," "doubtful integrity," "self-interest," "false wit," and "lively imagination" against his character. The major militant irony in her preliminary remarks is that Burke in his critique of the philosophical rationalism and rational morality on the grounds of which the French Revolution was launched did not "separate the public from the private" (p.5). His total disregard of self-government in the public sphere, Wollstonecraft tells Burke, paradoxically, makes his discourse sound as the discourse that he had already attributed to women in diverse writings of his. The lack of sincerity, irrelevance, and sentimentality are of some of its hallmarks. The idea is that Burke has involved himself in a gender switch with full knowledge, hence the liberty of tone that Wollstonecraft has taken with him in her assumption of manly attitudes in her discourse. This implied message in the medium of this discourse of gender permutations traverses the whole of the epistolary essay, investing Wollstonecraft with the authority to speak in the public sphere of politics.

Wollstonecraft's public authority expresses itself in the way she re-writes British constitutional history to deconstruct the hereditary rights that Burke elevates into rules of conduct at both the domestic and public spheres in total contempt of the abstract or natural rights of men based on reason. The major thread of her argument is that this constitutional history was driven not by the quest for freedom, as Burke tells us, but by the quest for hereditary property and hereditary honours pertaining to it. Wollstonecraft starts her history with a paraphrased reminder from John Locke's Two Treatises of Government to the effect that "the birthright of man [...] is such a degree of liberty, civil or religious, as is compatible with the liberty of every other individual with whom he is united in a social compact, and the continued existence of that compact" (1996, p.7). She follows up by saying that contrary to Burke's affirmation as to its realization in Britain, this idea of freedom still remains an ideal to be sought for since it had not yet taken shape in the various governments known to man until then. Following in the footsteps of Jean-Jacques Rousseau (1989) who considers property as the bane of freedom, she in her turn claims that "the demon of property has ever been at hand to encroach on the sacred rights of men, and to fence round with awful pomp laws that war with justice" (p.7). For Wollstonecraft, this claim was true as far as one can go back in the history of civilization. The outrageous tone in which Wollstonecraft makes this claim seems to indicate the extent to which women were always regarded as property to be 
fenced off in the manner of landed property. In this sense, Wollstonecraft announces what Frederick Engels would demonstrate later in the nineteenth century in his study of the origin of the family.

As if attempting to lay bare the textuality of Burke's constitutional history and dispel the aura of sanctity with which he surrounds some of the British institutions by invoking custom as practical reason against abstract reason, Wollstonecraft asks the following rhetorical question: "Will Mr. Burke be at the trouble to inform us, how far we go back to discover the rights of men, since the light of reason is such a fallacious guide that none but fools trust to its cold investigation" (p.9)? Following this, she takes the example of British constitutional history to illustrate the distortion to which Burke submits it in name of customs. For Wollstonecraft, these customs do not deserve at all to be objects of reverence or principles of conduct as understanding or reason, because at their basis is a history of compromises and political deals between the British Royalty, the Barons, and the Commons for the preservation of power and property at the expense of justice for the overtaxed people. Developed in the ages of ignorance, constitutional documents like Magna Charta are nothing more than naked power disguised as right sometimes in favour of the King, and at some other times in favour of Parliament and the Clergy. In defending customs, instead of abstract reason, Burke shows himself as a "champion of property [and] the adorer of the golden image which power has set up" (pp.11-12).

In his Discourse on Inequality, Jean-Jacques Rousseau (1999) writes that "The true founder of civil society was the first man, who, having enclosed a piece of land, thought of saying, 'This is mine, and came across people simple enough to believe him" (p.53). Arguably, the portrayal that Wollstonecraft draws of Burke puts him in the category of these simpler-minded people. Even more so, he champions property and in the manner of the Jews of the Exodus, he renounces to the faith in freedom by becoming the worshipper of the golden cow. In the same book Rousseau follows up the quote above with the following words that describe the posture that Wollstonecraft adopted in her $A$ vindication of the rights of men: "How many crimes, wars, murders and how much misery and horror the human race might have been spared if someone had pulled up the stakes or filled in the ditch, and cried out to his fellows: 'Beware of listening to this charlatan" (p.53). In its emphasis on crime, murders, wars, the text of Wollstonecraft's British history seems to have largely been shaped by Rousseau's view about the importance that inherited property assumed in human relationship in civil society. Her hard line against this kind of property sounds as if a manly "someone" at last in Britain had pulled up the stakes and cried out to his fellows: "Beware of listening to this Charlatan [Burke]." Rousseau's negative view of inherited property seems also to offer a philosophical foundation for Wollstonecraft's denunciation of the enclosures of the common lands near the end of $A$ vindication of the rights of men, enclosures, which in her view, caused so much misery for a large proportion of British people.

The feminism of Wollstonecraft also appears in her pulling up the stakes from the public sphere of political activity and engaging a debate on whether property rights supersedes other rights such the preservation of life, protection by law and so on. In this polemical debate with Burke, Wollstonecraft strongly distinguished between inherited property and the acquired type of property. While the former is identified as being at the source of all the corruptions that undermine civil society by its encouragement of vices like luxury, idleness and softness, the latter is valued positively since it is the result of physical and intellectual exertion. Wollstonecraft is incensed that Burke belittles the acquired material property of the bourgeois class and the acquired intellectual property of such men as Dr Price, who even in France would have been elevated to the status of gentlemen, while he makes such a big case of the honours that inherited property confers on the nobility and the ecclesiastical orders. In short, by re-writing the constitutional history of Britain in the manner of Rousseau's Discourse of inequality, Wollstonecraft does not solely seek to undermine Burke's disavowal of the Enlightenment ideals of progress, perfectibility of men's rational capacities and the enlargement of freedom and human emancipation on which the French Revolution was launched. Apart from Rousseau, two philosophical sources are heavily drawn on in this evaluation of property: Locke and Gibbon. Whilst Wollstonecraft aligns herself with Locke in her claim that it is physical and intellectual work that confers value to property, she evokes Edward Gibbon's of History of the decline and fall of the Roman Empire in her emphasis on the moral decadence of the British nation or empire brought out by inherited property.

To use Bonnie S. Anderson and Judith P. Zinsser's (1988) paraphrase of Virginia Woolf's essay title A room of one's own, Wollstonecraft also writes a history of her own at the same as she re-writes British constitutional history. In interweaving her own personal history with her account of British constitutional history, Wollstonecraft prefigures twentieth century's radical feminists' slogan that the personal is political and the political is personal. One would argue that if Wollstonecraft is particularly sharp on inherited property and privileges, it is because she herself deeply suffered from the feudal law of primogeniture that made the eldest son the sole inheritor of the father's estate, thus excluding senior daughters and junior brothers from inheritance. This short life story can help explain the intersection of the personal with the political, or rather the slippage from communal history text to familial or private history. Wollstonecraft was born on the $27^{\text {th }}$ of April 1759 in Spitalfields outside of London to a "dissipated and unthrifty" father who wasted his fortune by heavy drinking. According to Cracium Adriana (2002), still in her infancy, Wollstonecraft was deeply hurt by the favours piled on her junior brother Ned who as the eldest son was looked on as the sole heir to a dwindling family fortune out of which her two sisters and her were excluded on the basis of their sex. The feudal law of primogeniture was the gendered law that threw her on the road at the age of 19 in search for a means of livelihood to support herself and her dying mother. She moved all the way to Ireland, Portugal as a paid companion. When she came back home, she established a school that did not achieve remarkable success. In the course of this 
eventful and hectic life she came across Richard Price, a dissenting minister and liberal intellectual and fellow of the Royal Society who advocated political and economic reform. Price not only nurtured her idealism but he also catered for the lack of a good parental or fatherly figure and in a way bequeathed her an intellectual legacy that she invested with a good return by working for Johnson's Analytical review.

As if in echo of her family and personal history, Wollstonecraft expostulates as follows: "Who can recount the unnatural crimes which the laudable interesting desire of perpetuating a name has produced" (p.21)? After which she lists the misery of younger children sacrificed on the altar of the eldest children, and exiled, or "confined in convents, that they might not encroach on what was called, with shameful falsehood, the family estate.(Ibid.)" The perpetuation of property or family estates as a block, considered some political economists, as the basis for the start of capitalism, becomes an ideological site for contesting Burke's natural morality, by which he affirms that morality is but "inbred exalted instinct" in which reason plays no significant role. Wollstonecraft shows that with such morality, parental love becomes an artificial affection and self-love since the concern is to perpetuate a name, the son's liberty is stifled by fear of the father's curse and replaced by dubious homage to the father for his transference of property, and marriage turns into what Daniel Defoe calls "legal prostitution" (p.21). Natural morality is opposed to rational morality, wherein reason and understanding, concepts borrowed from John Locke, are the sole principles of conduct in a truly liberal society.

For Wollstonecraft, "the character of a master, a husband, and a father, forms the citizen imperceptibly, by producing a sober manliness of thought, and orderly behaviour, but from the lax morals and depraved affections of the libertine, what results"(p.22)? Arbitrary power in the patriarchal system is denounced as a moral violation of that God-given faculty through which manliness (men and women) can elevate itself above the brutish state of animals, and cultivate those noble virtues as citizens concerned with the affairs of both the earthly and celestial city. Contrary to the natural morality founded more on the observation of decorum and the respect of the sanctity of "antiquity," rational morality is liable to improvement and perfection as each individual and generation exerts its reason for self-government and the just government of the city. Taking natural morality as a contesting site over inherited property and the vices it generates, Wollstonecraft tells Burke that "property should be fluctuating [...] and equally divided among the children of the family. (p.23)" And if his major concern is to safeguard it, he has to learn that "the only security of property that nature authorizes and reason sanctions is, the right a man has to enjoy the acquisition which his talents and industry have acquired; and to bequeath them to whom he chooses" (p.23). Wollstonecraft also castigates that middle class category of people "aping the manners of the great," instead of promoting the ethic of work and the proprietary consciousness peculiar to their own class. The critique is double-pronged since it is meant to hit both Burke and her father who betrayed their own class.

Wollstonecraft's feminist critique of the family is similar to her critique of the British civil society as a whole. As she describes it, it is not as perfect as Burke makes it look like, because the same hereditary property and privileges undermine it from within. The monarchy cannot be really called Constitutional since in his refutation of Dr. Price Burke tells us that "the succession of the King of Great Britain [does] not depend on the choice of the people" (p.19). This is another way of saying that power is the sole inherited property of the King. This power, fallaciously disguised as a hereditary right, corrupts courtly life and the social fabric. Representational democracy became a sham as elections were rigged, political merit was demeaned, nepotism was encouraged and true faith or religion was sold out by the clergy, in the name of hereditary rights and honorary privileges. This picture that Wollstonecraft gives of the Britain of her time in response to Burke's idealization of the British Constitution does not differ much from the one drawn by French Enlightenment philosophers of the French Old Regime of the Three States. The implication is that Britain needed the same radical economic and political reforms undertaken in France in spite of Burke's claim that Britain was past the age of revolution and reformation. Notwithstanding the "horselaugh" that Wollstonecraft imagines to hear from Burke in uttering this claim, she develops the idea that the new political rationalism guiding the discussion of the new French Assembly is much better than the antiquarianism of the British political system based on "exalted instinct" instead of reason.

As noted earlier, the form or style of Wollstonecraft's essay constitutes the major feminist message. Unless the ideology of form is attended to, the way our author "ungenders" or dislodges gender will be missed. As one reads through the essay, one can notice that the author reproaches Burke his Gothicism, or medievalism, which is part and parcel of the antiquarian movement that rose as a response to the Industrial Revolution. As a result of this Industrial Revolution, there arose nostalgia for the medieval or gothic period out of which Burke creates a usable sacred past to weather out the political disturbance caused by the French Revolution. It has to be observed that Burke is also the author A philosophical enquiry into the origins of the sublime and the beautiful meant as a "theory of passions." In this theory, he places under two broad categories, passions related to self-preservation and those related to society, the latter being subdivided into the passions belonging to the society of sex and those of society in general. Burke's theory of passions is underlined by a well-marked gender politics since he tells us that while the passions of self-preservation are most male passions those belonging to the society of sex are female. The former are associated with pain and danger whereas the latter are linked to love and procreation. In terms of aesthetics, the sublime and the beautiful are properties of represented objects and ideas transmitted by the five senses through various artistic modes. So, "what is fitted in any sort to excite the ideas of pain and danger, that is to say, whatever is in any sort terrible, or is conversant about terrible 
objects, or operates in a manner analogous to terror, is a source of the sublime; that is, it is productive of the strongest emotion which the mind is capable of feeling" (p.13). The properties that excite the feeling of greatness or sublime are vastness, infinity, obscurity, darkness, privation, interrupted succession or non-uniformity, magnificence, each of them attached to one of the senses. On the contrary, the beautiful is a "social quality" that emanates from objects, which excites the pleasure of love by properties such as smallness or littleness, smoothness, sweetness, sentimentality, light, and so on. If beauty is defined as a "social quality" it is because it has no link neither with physical fitness, perfection, proportion, nor with qualities of the mind like courage and fortitude.

The sublime and the beautiful, Burke argues, can be linked to virtues, but these virtues are gender marked as soft and heroic. The soft virtues are feminine and the heroic ones are masculine. It is this gendered, binary aesthetics that Wollstonecraft overturns in her $A$ vindication of the rights of men. Among other reproaches, she takes Burke to task for giving up to that the sentimental language that he has himself assigned to women in his description of the British political and religious establishment. He grows tragically tearful over the deposed Queen Mary Antoinette just because her person was mobbing women belonging to the vulgar. Burke does not know that the injustice that the Queen shares with them a refined vulgarity. In short instead of appreciating the sublime in the historical text written by the French Revolution and welcoming the reform of abuses promised by that Revolution as the majority of his contemporary fellow intellectuals and politicians like Gibbon and Price did, Burke abandoned himself to the sentimental and beautiful for the simple pleasure of appearing an exception to the rule. Wollstonecraft wonders whether Burke would not have done the contrary, had the majority of British people not taken a positive view of the French Revolution.

To the beautiful feminine properties of Burke's discourse in Reflections on the revolution in France, Wollstonecraft opposes the sublime counter-discourse of her $A$ vindication of the rights of men. The sublime feelings are elicited by a strong commitment to confronting courageously the danger of political innovation and not escaping the pain that political change can bring out. For Wollstonecraft, the Revolution in France puts on stage ideas like justice, equality and fraternity whose properties inspire similar sublime feelings and reasoning as those that Burke describes in his $A$ philosophical enquiry into the origin of our ideas of the sublime and beautiful. By engaging Burke on the grounds of his own aesthetic theory, Wollstonecraft does not solely puts into relief his own intertextual and intratextual inconsistencies but also puts him to shame by subtly comparing him to those beautiful scribbling women of her time who adulterated the political rationalism of essay writing by giving free rein to the play of imagination characteristic of fanciful romances. Burke emerges out of her text as a quixotic pathetic "hero," who enamored of feudal gothic antiquities, became unable to follow the march of historical progress that the Revolution in France foreshadowed.

\section{CONCLUSION}

Wollstonecraft's very aggressive and self-righteous prose pushes Burke to Gothic self-destruction by exposing his excessively aristocratic inconsistencies like his dueling with Dr. Price just for obtaining "satisfaction." Wollstonecraft pays him back in his coin in order to rehabilitate a new political and economic system defended by her mentor (Price), a system based not on aristocratic blood privileges but on bourgeois merits. So, contrary to what happens in Gothic fiction, the Gothic heroine Wollstonecraft does not seek the rehabilitation of a mother victimized by the aristocratic patriarchal system, but that of a fantasized civilized father unjustly suspected about his patriotism by a rear-guard conservative (Burke) who has come to the rescue of a residual ideology that makes Britain look like the France of the Old Regime. For the rescue of the good mother from oblivion, the heroine posing as a victim, and other such formal characteristics that Hoeveler identifies as characteristic of Gothic feminism, one has to look for them in Wollstonecraft's $A$ vindication of the rights of woman.

\section{REFERENCES}

[1] Bakhtin, M. (1999). Problems of Dostoevsky's poetics, Minneapolis: University of Minnesota Press.

[2] Bhabha, H. K. (1991). Narrating the nation. In Bhabha H. K. (Ed.) Nation and narration. London: Routledge.

[3] Benedict, A. (1991). Imagined communities: Reflections on the origin and spread of nationalism. London: Verso.

[4] Bonnie, A., \& Zinsser, J.P. (1988). A history of their own: Women in Europe from prehistory to the present (Vol. 1). London: Penguin.

[5] Burke, E. (1958). A philosophical enquiry into the origin of our ideas of the sublime and the beautiful. London: Routledge.

[6] Colley, L. (1992). Britons: Forging a Nation, 1707-1837. New Haven: Yale University Press.

[7] Eagleton, T. (2002). Marxism and Literary Criticism. London: Methuen.

[8] Cracium, A. \& Kari E.L. (Eds.). (2001). Rebellious hearts: British women writers and the French Revolution. Albany: State University of New York.

[9] Foucault, M. (1991). Discipline and punish: The birth of the prison (A. Sheridan, Trans.). London: Penguin.

[10] Foucault, M. (1990). The history of sexuality (Vols. 1- 3) (R. Hurley. Trans.). New York: Vintage.

[11] Foucault, M. (2005). The birth of the clinic: An archaeology of medical practice (A. M. Sheridan. Trans.). London: Routledge.

[12] Gibbon, E. (1966) The history of the decline and fall of the Roman Empire (Vols. 1-6). London: Everyman.

[13] Habbermas, J. (2010). The structural transformation of the public sphere: An inquiry into a category of bourgeois society. (Thomas Burger, Trans.). Cambridge: Polity Press. 
[14] Hawkins, L. M. (2003). From Letters on the French Mind and Pursuits Addressed to Miss H.M Williams with Particular Reference to her Letters from France. In V. Jones, (Ed.). Women in the eighteenth century: constructions of femininity, London: Routledge.

[15] Hoeveler, D. L. (1998). Gothic feminism: The professionalization of gender from Charlotte Smith to the Brontès, Liverpool: Liverpool University Press.

[16] Hume, D. (1963). Essays: Moral, political and literary. London: Oxford University Press, 1963.

[17] Liu, A. (1989). Wordsworth: The sense of history. Stanford: Stanford University Press.

[18] Locke, J. (1996). Some thoughts concerning education and Of the conduct of the understanding. Indianapolis: Hackett Publishing.

[19] Newman, G. (1987). The rise of English nationalism: A cultural history, 1740-1830. New York: St. Martin's.

[20] Rousseau, J.J. (1989). Discourse on inequality. (F. Philip, Trans.) Oxford: Oxford University Press.

[21] Rousseau, J.J. Emile ou de l'éducation and Emile et Sophie ou les solitaires. In Euvres Complètes, (Vols. 1-4). Paris: Le seuil, 1969.

[22] Rendell, J. (1985). The origins of modern feminism: Women in Britain, France and the United States 1780-1860. London: Macmillan.

[23] Spivak, G. Ch. (1987). In other worlds: Essays in cultural criticism. New York: Methuen.

[24] Wellington, J. (2001). Blurring the borders of gender: Mary Wollstonecraft's Character (R)evolution. In A. Cracium \& and K. Lokke, (Eds.). Rebellious hearts: British women writers and the French Revolution (pp.33-61). Albany: State University of New York.

[25] Wollstonecraft, M. (2008) A vindication of the rights of men; A vindication of the rights of woman; An historical and moral view of the French Revolution. Oxford: Oxford University Press. All references in the text are made to this edition.

[26] Wollstonecraft, M. Thoughts on the Education of Daughters: with Reflection on the more Important Duties of life. In V. Jones (Ed.). Women in the Eighteenth Century: Constructions of Femininity. London: Routledge, 2003.

[27] Wollstonecraft, M. (1989). Letters Written during a Short Residence in Sweden, Norway and Denmark. In J. Todd \& M. Butler, (Eds.). The Works of Mary Wollstonecraft. London: William Pickering.

[28] Yuval, D. (1997). Gender and Nation, London: Sage.

Gariti Mohammed is maître de conferences (B) in the Department of English, Mouloud Mammeri University of Tizi-Ouzou, Algeria. His research interests include feminism, British civilization and literature. He is currently involved in a research team working on a comparative study of Algerian and Indian Literatures.

Sabrina Zerar is a maitre de conferences (A) in the Department of English, Mouloud Mammeri University of Tizi-Ouzou, Algeria. She is currently directing a research team on cultural and gender studies commissioned by the Algerian Ministry of Higher Education and Scientific Research. She is author of several articles on feminism published in international journals. 